DOI https://doi.org/10.36059/978-966-397-213-8/122-152

\title{
PART 5. THE SUFFERING PATH OF THE CHURCH IN THE SECOND HALF OF THE 1940s - 1980s
}

The activities of the Initiative Group gave reasons to the state security authorities to move to the next stage of implementation of the general plan for the liquidation of the UGCC. In September 1945, the National Security Service of the UkrSSR developed appropriate measures to accelerate the process of transition of the Uniate priests to the Orthodox Church. It was planned to hold diocesan congresses at which this issue would be agreed in the dioceses. However, the rejection of such an idea by a large part of the priests, and by G. Kostelnyk himself, forced the Chekists to take into account the specificity of the canon law.

In December 1945, at the NCSD of UkrSSR, it was decided to prepare the General Church Council of the UGCC (the Galician Council) as "the only canonical form of organizational consolidation of the liquidation of the Greek Catholic Church and its reunification with the Orthodox Church". As stated in the corresponding letter of S. Savchenko to V. Merkulov, the convening of such a "council will be the most sensual blow to the Vatican, ...it will break the ground of the "nationalist bandit underground of the OUN and other terrorist groups and will create preconditions for the use of Uniate priests in the Orthodoxy for religious and patriotic work in the western regions of Ukraine". People's Commissar S. Savchenko assured that the opportunities of the authorities at that time "fully guarantee the holding of the "Galician Council" in the desirable for us direction", and asked to allocate 500,000 rubles for these events. At the end of January 1946 a telegram came from V. Merkulov, which reported about the permission to hold a church council, allocation of over 400 thousand rubles to ensure this event, as well as the recommendation to avoid the name of council as "Galician"371.

371 Ліквідація УГКЦ (1939-1946): документи радянських органів державної безпеки. К.: ПП Сергійчук М.I., 2006. Т. 2. С. 497-498. 
Appropriate measures were also carried out by the Soviet authorities. In mid-December 1945, in Kyiv, a joint meeting of the Commissioners of the Council of the ROC and the RSRK took place at the regional executive committees of the western Ukrainian regions, in which, in addition to the republican heads of these structures P. Khodchenko and P. Vilkhovyi, Moscow leaders G. Karpov and I. Polyansky also participated. This meeting outlined a general approach to the organization and holding of the council. The meeting was followed by another in a narrow circle, which discussed the readiness to convene a "council of representatives of the Greek Catholic clergy to formally approve and announce the act of breaking with the Vatican and reuniting with the Russian Orthodox Church",372. After this meeting, G. Karpov and I. Polyansky attended a reception at the chair of the UkrSSR, M. Khrushchev and his deputy L. Korniets, where, according to P. Khodchenko, approved the measures for the preparation of the council.

In the process of elaborating this problem, the chronological boundaries for the implementation of this event were determined the first decade of March 1946, which was dedicated to the so-called "Orthodoxy Week". Thus, the holding of the council by the authorities of the UGCC priests pursued the aim of legalizing by church and canon law the actual state of the church's defeat, which was carried out at that time by the active methods of the authorities and the repressive bodies.

The structures of the NSCD have formed an extensive intelligence network for the systematic secret collection of information regarding the UGCC. In order to prevent any unforeseen actions, numerous arrests have been made among the Greek Catholic clergy. During the period of restoration of the Soviet authorities (from the summer of 1944 to March 1946), 287 people were arrested "on the Uniate line", including 1 metropolitan, 4 bishops, 182 priests, 11 monastery chairmen, 6 deacons, 23 monks, 9 students of theological academy and other believers connected with the activities of the nationalist underground or units of the $\mathrm{UPA}^{373}$. Under the jurisdiction of the

\footnotetext{
372 ЦДАГО України. Ф. 1. Оп. 23. Спр. 1639. Арк. 149-150.

373 Ліквідація УГКЦ (1939-1946): документи радянських органів державної безпеки. К.: ПП Сергійчук M.I., 2006. T. 2. С. 518.
} 
G. Kostelnyk Initiative Group, 1805 parishes led by their pastors were replaced by administrative methods. Often, written commitment was obtained through "individual processing" and during the clergy meetings.

Thus, from the organizational point of view of the Soviet authorities, the necessary preconditions were created for holding a council at which the expected decisions had to be adopted. To deprive any possibility of avoiding direct or indirect participation in the planned action, the authorities once again went on a demonstrative intimidation. On March 1, 1946, in the newspapers of the western regions of Ukraine, a message from the Prosecutor of the UkrSSR R. Rudenko was published about the charges of the hierarchs of the church arrested in 1945 (J. Slipyj, G. Khomyshyn, M. Charnetsky, M. Budka, I. Lyatyshevsky, and others.) $)^{374}$. The arrested were accused of active cooperation with the German authorities, assistance in the "armed struggle of the German invaders against the Red Army", "their participation in the formation of the SS division "Galicia" to fight the guerrilla movement and the Red Army". Such allegations came under the qualification of Articles 54-I and 54-II of the Criminal Code of the UkrSSR - "betrayal of the motherland, that is, actions committed by citizens of the USSR to the detriment of the military strength of the USSR, its state independence, namely: espionage, extradition of military or state secrets, moving to the side of the enemy, escape or flight abroad", for which a higher punishment was assumed - execution with confiscation of property, and in mitigating circumstances - 10 years' imprisonment also with confiscation of property.

However, in the message to the Central Committee of the Communist Party (b) the secretary of the Lviv Party Committee I. Hrushetsky noted that a significant part of believers met the message of the Prosecutor of the UkrSSR, as well as the news about the church council ambiguously, in most of the documents cited as negatively ${ }^{375}$.

\footnotetext{
374 Гайковський М.І.Хресною дорогою: Функціонування і спроби ліквідації Української Греко-Католицької Церкви в умовах СРСР у 1939-1941 та 19441946 роках: збірник документів і матеріалів/ упоряд.: Гайковський М.І. Львів: Місіонер, 2006. С. 330.

375 ДАЛО. Ф. П-3. Спр. 424. Арк. 48-51.
} 
In order to increase the level of representation of clergy at the council, it was decided to consecrate several of them as bishops. Representatives of the Council on Religious Affairs and ROC under the Government of UkrSSR P. Hodchenko and P. Vilkhovy in the letters to Moscow Patriarch Alexey and the Exarch of Ukraine Ioann, proposed to nominate and immediately consecrate at least two bishops among the Uniate priests. Among the most likely priests the most acceptable candidates were the members of the Initiative Group M. Melnyk and A. Pelvetsky, who proved themselves to be reliable leaders of the policy of the Soviet authorities and were supported by G. Kostelnyk ${ }^{376}$.

To fulfill this requirement, on the submission of the Initiative Group, according to the characteristic of the secretary of the Initiative Group S. Khrutsky, there had been selected ten the "most prominent and authoritative" Greek Catholic priests, who went to Kyiv. On February 22, they took part in a solemn liturgy celebrated by the Metropolitan of Kyiv and Galicia, Exarch of Ukraine Ioann. After that, A. Pelvetsky and M. Melnyk were consecrated in monastic order. On the same day, during the evening Mass at the Volodymyr Cathedral, with the participation of the senior hierarchs of the Ukrainian exarchate of the ROC, the act of appointing candidates for bishops took place, and on February 24-25, an ordination (consecration) of A. Pelvetsky and M. Melnyk was held. The first was appointed as bishop of Stanislav Eparchy, and the second as the bishop of Sambir-Drohobych Eparchy of ROC ${ }^{377}$.

The Soviet authorities, by all possible means, facilitated the activities of the newly ordained Orthodox bishops. Thus, after the formation of the Stanislav Orthodox Eparchy within the administrative-territorial areas at the regional executive committee, there officially was established a department for the affairs of the Russian Orthodox Church $^{378}$. At that time, the Orthodox Eparchy of

${ }^{376}$ ЦДАГО України. Ф-1. Спр.1638. Арк. 130-135.

377 Гайковський М.І.Хресною дорогою: Функціонування і спроби ліквідації Української Греко-Католицької Церкви в умовах СРСР у 1939-1941 та 19441946 роках: збірник документів і матеріалів/ упоряд.: Гайковський М.І. Львів: Місіонер, 2006. С. 324-326.

378 ДАІФО. Ф. Р-389. Спр. 3. Арк. 9. 
the ROC consisted of only four officially registered parishes in the cities of Stanislav, Halych, Snyatyn and Kolomya ${ }^{379}$.

After solving the task of providing the council with the bishops' presence, the authorities worked out the agenda of the council and a clear plan for its holding. On the eve of the council on March 6, 1946, a meeting of 18 priests was held at the apartment of the head of the Initiative Group G. Kostelnyk. Among the topics of the speeches there were: motives for reunification of the Greek Catholic Church with the Russian Orthodox Church; church issues related to turning to the Orthodox Church; territorial division of eparchies and deaneries according to the state administrative division into regions and districts $^{380}$.

The Soviet authorities closely monitored both the preparations for the council and its course. Since the beginning of March, Karpov communicated daily with Kyiv and Lviv, sending instructions and recommendations, and requesting regular updates on the progress of the council ${ }^{381}$. G. Karpov gave instructions to a delegate to Lviv, Utkin, and a local SRRS commissioner in the Lviv region, Vyshnevsky, to inform him every day from March 5 to March 10 on the events ${ }^{382}$.

Colonel S. Karin together with Captain O. Bogdanov, carried out direct organization of the relevant events on the line of the National Security and Defense Council and were responsible for holding the arrival and accommodation of the participants, giving food stamps, general protection of the place of the church meeting - St. George's Cathedral and hotels where the delegates settled. General coordination of activities, related to the plan, was carried out by the Deputy Commissar of the National Security Service of the UkrSSR, Lieutenant General P. Drozdetsky ${ }^{383}$.

\footnotetext{
379 Ibid

${ }^{380}$ ДАІФО. Ф. Р-389. Спр. 3. Арк. 5.

381 Білас І.Г. Репресивно-каральна система в Україні. 1917-1953: Суспільнополітичний та історико-правовий аналіз. Кн.2: Документи і матеріали. К.: Либідь - Військо України, 1994. С. 300.

382 Ibid. C. 301.

383 Сердюк Н.С. Репресії радянських органів державної безпеки щодо Української греко-католицької церкви в 1944-1949 рр.: автореф. дис. на здобуття наук. ступеня канд. іст. наук: спец. 07.00.01 «Історія України». К., 2006. С. 14.
} 
The authorities provided not only ideological and organizational but also financial support for the action to eliminate the UGCC. According to the order of the RNA of the USSR from January 24, 1946, signed by V. Molotov, there were allocated 400 thousand rubles from the government reserve fund for various expenses associated with the council ${ }^{384}$.

Scientific literature contains controversial information about the number of Greek Catholic priests who supported the Initiative Group on the eve of the council. A. Pelvetsky in his speech at the council said that 986 priests joined the Initiative Group and 281 clergymen $^{385}$ did not support its activity, which means the total number of priests was 1267. According to the Ukrainian researcher O. Utkin, the Initiative Group had an influence on 997 and general number of the priests was 1,270. The research of the Russian researcher D. Pospelovsky states that there were 2000 Greek-Catholic priests in total, but at the time of the council there were not imprisoned $1297^{386}$, and 997 supported "reunification" with the ROC ${ }^{387}$.

Undoubtedly, the accuracy of all these calculations is sufficiently conditional, mainly taken from the Soviet sources, as indicated by V. Sergiychuk. According to the data given by him, in December 1945, there were 2,286 Greek Catholic communities ${ }^{388}$ in four Galicia regions. That means that even the part of the priests who in fact were engaged in spiritual activity could not fully provide the pastoral mission in these communities.

According to the council's mandate commission, there were invited 225 delegates-priests - members of the Initiative Group and 22 delegates from laymen from three Greek-Catholic eparchies (Lviv, Sambir-Drohobych and Stanislav), 216 priests and 19 lay people

384 ДАЛО. Ф. Р-1332. Оп. 1т. Спр. 4. Арк. 20-23.

385 Діяння Собору УГКЦ 8-10 березня 1946 р. Львів: Видання Президії Собору, 1946. С. 61.

386 Уткін О. Львівський церковний собор 1946 р. в контексті тогочасних політичних реалій. Украӥнський історичний журнал. 1998. № 5. С. 109.

387 Поспеловский Д. Православная церковь в истории Руси, России и СССР: учеб. пособ. М.: Библейско-богословский институт Св. Апостола Андрея, 1996. С. 218.

388 Сергійчук В. Греко-католицька церква в 1944-1991 pp. Український історичний журнал. 1996. № 4. С. 112. 
arrived. The invited priests who did not join the Initiative Group, refused to participate in the council. According to J.Herych, the number of participants was much smaller than that presented by the mandate commission and A. Pelvetsky, and did not exceed 140 people $^{389}$.

On the morning of March 8, 1946, the Lviv Council began its work. The procedure of this action in a sublime and commendable tone was transmitted in the edition of the "Actions of the UGCC Council on March 8-10, 1946 in Lviv", issued immediately after its completion $^{390}$. The first reporter on the activities of the Initiative Group was the bishop of the Russian Orthodox Church A. Pelvetsky. In his report, he outlined the purpose of the work of the Council: "Before the normalization of church life, only the Council can open the door to us, which will confirm our return to the Orthodox Church",391.

After that, A. Pelvetsky, G. Kostelnyk made a report on the motives for reunification of the Greek Catholic Church with the Russian Orthodox Church. The main report of the council G. Kostelnyk began with the history of the Union, trying to convince the audience that Rome systematically and consistently used the Union of Brest to absorb Orthodoxy ${ }^{392}$.

The basis of G. Kostelnyk's report was the provisions set out in letters to the RNA and priests in May 1945. After his speech, a "discussion" began, in which pre-determined co-reporters with edited texts took part. All of them were in support of the proposals of the narrators A. Pelvetsky and G. Kostelnyk.

After that, it was proposed to proceed to the voting procedure. It took place in an open mode, with a rising of hands, with the voting

389 Герич Ю. Як відбувався «возсоєдинительний собор» у Львові 8 березня 1946 р. Календар «Світла». Торонто; Нью-Йорк, 1995. С. 88.

390 Діяння Собору УГКЦ 8-10 березня 1946 р. Львів: Видання Президії Собору, 1946. С. 35 .

391 Гайковський М.I. Хресною дорогою: Функціонування і спроби ліквідації Української Греко-Католицької Церкви в умовах СРСР у 1939-1941 та 19441946 роках: збірник документів і матеріалів / упоряд.: Гайковський М.І. Львів: Місіонер, 2006. 650 c.

392 Львівський церковний собор: документи і матеріали. 1946-1981. К., 1984. C. 65 . 
being watched by both the staff of the National Security and Defense Agency and the cinema lenses that filmed the "historical council" for the newsreel. Accordingly, the delegates unanimously supported the draft of the decision in four points: "1) to annul the Brest Union regulations of 1596 ; 2) to break away from the Roman (papal) Church; 3) to return to the Orthodox faith of the predecessors; 4) to reunite with the All-Orthodox Church in the Soviet Union"393. Further, several documents were unanimously adopted ${ }^{394}$. The main document was the resolution of the council ${ }^{395}$.

Although the council was no longer deciding the fate of the UGCC, since at that time it was essentially defeated, its decisions allegedly legitimized the process. Therefore, the main planned task of the council was fulfilled on the first day of its work ${ }^{396}$.

The next day, March 9, the process of church-canonical registration of the transition to Orthodoxy took place. In the St. George's Cathedral, 12 priests, who reunited with the ROC in Kyiv in February 1946, were confessed. The council considered the issue of "canonical registration", the decision on "reunification", and during the joint liturgy conducted by Bishops Makariy, Antonyi and Mykhail, bishop Makariy fulfilled the act of "joining to the Orthodox Church", after accepting the refusal of Catholicism by the 204 delegate priests. After the liturgy, a memorial service for the peace of the soul of Metropolitan A. Sheptytsky took place immediately, which, after the attacks on his name by the authorities, could be regarded as a concession by the organizers of the council to these "reunited" priests to appease their conscience.

After the liturgy, the council continued its work. In particular, a number of appeals and greeting telegrams were approved. The "Address of the Council to the Clergy and Believers of the Greek

\footnotetext{
${ }^{393}$ Ibid. C. 75.

394 Герич Ю. Як відбувався «возсоєдинительний собор» у Львові 8 березня 1946 р. Календар «Світла». Торонто; Нью-Йорк, 1995. С. 256-257.

395 Львівський церковний собор: документи і матеріали. 1946-1981. К., 1984. С. 127-128.

396 Гайковський М.І. Хресною дорогою: Функціонування і спроби ліквідації Української Греко-Католицької Церкви в умовах СРСР у 1939-1941 та 19441946 роках: збірник документів і матеріалів / упоряд.: Гайковський М.І. Львів: Місіонер, 2006. С. 364-365.
} 
Catholic Church in the Western Regions of Ukraine" gave reasons for the elimination of the Union of Brest in 1596, the break with the Vatican, and reunification with the Orthodox Church. In an address to the Patriarch Alexy of Moscow and All Russia, the delegates requested "to recognize our resolution and to accept us to the AllRussian Orthodox Church", certifying it with their signatures ${ }^{397}$.

Finally, the participants of the council approved changes in church-administrative, marriage, liturgical practices. From now on, the eparchy operated within the existing regional administrative division. The final part of the work of the council was occupied by a ceremony with the participation of the Metropolitan of Kyiv and Galician, Exarch of Ukraine Ioann. G. Kostelnyk in favor of Metropolitan resigned as the head of the Initiative Group, as such, who had fulfilled its task. Metropolitan read a letter of congratulation from the Patriarch of Moscow, in which the Greek Catholic Church was accepted to the Orthodox Church and handed it to G. Kostelnyk ${ }^{398}$.

Addressing the participants of the council, Metropolitan Ioann expressed a clear desire of the Moscow Patriarchate to subordinate the UGCC, to strengthen greatly themselves and their influence on the believers. "I pray with all my heart," he urged, "that the present triumph should be the beginning of the complete elimination of the Uniate in our country, and then Christians, not only of the whole of Ukraine but of our Union, will form one bonded family of love, one flock under the control of a single shepherd - the holy patriarch of Moscow" 399 .

On March 10, in the St. George's Cathedral the church service was held with the participation of guests, other ceremonies and a joint dinner at the restaurant of the "Bristol" Hotel. After that, the delegates left for their homes ${ }^{400}$.

\footnotetext{
397 Діяння Собору УГКЦ 8-10 березня 1946 р. Львів: Видання Президії Собору, 1946. С. $133,137-139,141-145$.

398 Діяння Собору УГКЦ 8-10 березня 1946 р. Львів: Видання Президії Собору, 1946. C. $118-122$.

399 Ibid. C. 125.

400 Гайковський М.І.Хресною дорогою: Функціонування і спроби ліквідації Української Греко-Католицької Церкви в умовах СРСР у 1939-1941 та 19441946 роках: збірник документів і матеріалів / упоряд.: Гайковський М.І. Львів: Місіонер, 2006. С. 365-366.
} 
At the beginning of April 1946, members of the former Initiative Group, G. Kostelnyk, M. Melnyk and A. Pelvetsky arrived in Kyiv, where they met with M. Khrushchev and M. Grechukha. They gave the documents approved by the Lviv Council to the leaders of the UkrSSR, had a conversation about bringing the decisions of the council to the masses, and about the publication of the book "Actions of the Lviv Council’"401.

On April 4, the Lviv delegation arrived in Moscow, where it was received by Patriarch Alexy. They read and gave him a petition for joining the Orthodox Church. Subsequently, the delegation attended a wide reception hosted by G. Karpov for Patriarch Alexy, Metropolitan Ioann and members of the Lviv delegation headed by G. Kostelnyk. At the same time, instructions signed by G. Karpov for the registration of priests and parishes were sent to places in connection with the "reunification" of the Greek Catholic Church with the ROC, which regulated the procedure for registration, indicating that the "reunited" priests and deacons, as well as congregations (communities) must be registered immediately ${ }^{402}$.

In Moscow, the members of the delegation in the interview to a TARS correspondent substantiated not only the church-canonical but also the political and ideological grounds. The impersonal answers to the questions were more indicative of the editorial style of the district party ideology instructor than of the clergy ${ }^{403}$. After the trip to Kyiv and Moscow, the practical mission of the members of the former Initiative Group was completed.

Despite the decisions of the Lviv Council, a significant number of Greek Catholic priests continued to actively and passively resist the measures taken by the Soviet authorities to completely eliminate the UGCC. In April 1946, a special message from the chief of the Lviv Regional Office of the NKVD, Voronin, to the higher authorities indicated numerous examples of the negative reaction of Greek

401 Пащенко В. Греко-католики в Україні (від 40-х років XX століття до наших днів). Полтава, 2002. С. 218.

402 ДАЛО. Ф. Р-1332. Оп. 1т. Спр. 5. Арк. 9.

403 Львівський церковний собор: документи і матеріали. 1946-1981. К., 1984.

C. 98-99. 
Catholic priests to the council and its decisions, their willingness to continue their religious activities in the Uniate rite.

It should be noted that the UPA command and the leadership of the OUN underground supported resistance to the violent annexation of the UGCC to Orthodoxy. They conducted widespread outreach activities, exerted moral pressure on the clergy, which was subject to government pressure. However, there have also been cases of murders of priests who converted to Orthodoxy ${ }^{404}$. According to the official authorities, by the end of 1946, in the Stanislaviv region, in the face of fear of possible reprisal by the UPA, 22 priests abandoned the transition to Orthodoxy and terminated their duties to the Initiative Group. In the Ternopil region, 55 Greek Catholic priests motivated their refusal by the fear of possible repression by the nationalist underground ${ }^{405}$.

Despite the pressure from the authorities and the new church leadership, some priests and believers in the UGCC have refused to convert to Orthodoxy ${ }^{406}$. In total, by the end of 1946,1111 or $43 \%$ of the Greek Catholic priests had moved to the ROC, including 532 from the Lviv Eparchy, 203 from Przemysl, and 277 from Stanislaviv. According to I. Bilas, as a result of the mass arrests, at least 1,600 priests were sent in prisons and camps, and several hundred went on to illegal status, many of them continued pastoral service $^{407}$.

Thus, in 1946, the Council of Lviv did not become a moment of decisive turning of the Uniate clergy and faithful to Orthodoxy, as was expected by the Soviet government and the ROC hierarchs. It was only one of the stages of the process of liquidation of the Greek Catholic Church, an integral part of the anti-union policy of the

\footnotetext{
404 Лисенко О. Церковне життя в Україні. 1943-1946 pp. К.: Інститут історії України НАНУ, 1998. С. 324.

405 Стоцький Я. Українська Греко-Католицька Церква і релігійне становище Тернопільщини (1946-1989). Тернопіль, 2003. С. 34-35.

406 Гайковський М.I. Хресною дорогою: Функціонування і спроби ліквідації Української Греко-Католицької Церкви в умовах СРСР у 1939-1941 та 19441946 роках: збірник документів і матеріалів/ упоряд.: Гайковський М.І. Львів: Місіонер, 2006. С. 417-418.

407 Білас І., Репресивно-каральна система в Україні 1917-1953 Суспільнополітичний та політико-правовий аналіз. К.: Либідь, 1994. Кн. 1. С. 130.
} 
Soviet regime in the overall process of Sovietization of the Western Ukrainian lands in the post-war period. The only achievement of the initiators of the council, if it can be treated as such, was imitation of legitimacy and an attempt to present a violent action to the world as a "free will of the Ukrainian people".

However, these efforts were unsuccessful, as evidenced by the reactions and feedbacks in the press of the state bodies and numerous Ukrainian diaspora. It was obvious to the world society that a largescale action to liquidate the Ukrainian Greek Catholic Church at the Lviv Council in 1946 was carried out jointly with Communist regime and the Russian Orthodox Church in its interests. It was directed against the Vatican and Catholicism and aimed to weaken their position in the Christian world.

The Soviet side monitored the reaction of the Western world, carefully recording the responses of the world press, generating relevant information reviews based on them. One such review contained excerpts from various leading newspapers in Europe and the United States concerning the fate of the Ukrainian Church. In particular, the American "New York Times" on March 17, 1946 published materials on the decision of the Lviv Council and a negative statement by Cardinal Tisseran regarding the repression against the church and believers in Western Ukraine ${ }^{408}$.

UGCC hierarchs of the Ukrainian diaspora also condemned the Soviet regime and the leadership of the Russian Orthodox Church for the violent illegal and non-canonical affiliation of the Uniate Church with the Orthodox Church. On behalf of Ukrainians of Greek Catholic Canada, they stated, "As citizens of Canada, we demand that the freedom proclaimed by the Atlantic Charter extends to those unfortunate people who are being persecuted by the Soviets, we demand the liberation and right to return to their parishes and cease persecution of the Ukrainian Catholics"409.

\footnotetext{
408 ДАЛО. Фонд П-3. Оп.1. Спр.439. Арк. 46-47.

409 Гайковський М.І. Хресною дорогою: Функціонування і спроби ліквідації Української Греко-Католицької Церкви в умовах СРСР у 1939-1941 та 19441946 роках: збірник документів і матеріалів / упоряд.: Гайковський М.І. Львів: Мicioнep, 2006. С. 390.
} 
Representatives of the Ukrainian Autocephalous Orthodox Church continued their support for the persecuted UGCC, which continued to operate outside the Soviet occupation zone of the Ukrainian and Eastern European territories. In particular, the participants of the Second Council of Bishops of the UAOC under the chairmanship of Metropolitan Polycarp (Sikorsky), held from March 14 to 18, 1946 in the German town of Essling-on-Necker, approved the appeal to all Christian churches, as well as a separate appeal to the Catholic Church, which contained condolences about the forcible accession of the Greek Catholics to the ROC. Bishop I. Teodorovych, on behalf of the clergy and believers of the Ukrainian Autocephalous Church in North America protested, so as Exarch Ladyka and Bishop Savariy from the Ukrainian Catholic Church in Canada.

The Second Congress of Ukrainians of Canada in June 1946 adopted a special resolution stating that it was "protesting to the whole cultural and freedom-loving world against the violent intervention of the Soviet government in the cause of the faith of the Ukrainian people and the use of the Russian Orthodox Church to consolidate its dictatorship over the Ukrainian people" ${ }^{\text {"410 }}$.

The defeat of the UGCC was particularly painful and outrageous with the representatives of the Foreign Office of the Ukrainian Supreme Liberation Council (UHVR) and OUN foreign units, as well as a large number of Western Ukrainian emigrants. In connection with the tragic events at home, UHVR issued in May 1946 an appeal to all Ukrainians abroad ${ }^{411}$. In another statement, the leadership of UHVR informed the world society that in Ukraine "the religious sentiments of the Ukrainian population are being harassed by Bolsheviks... The whole action was aimed at: a) destroying the Greek Catholic Church as a religiously national institution that very seriously protects the Ukrainian people from the Russification influences of Moscow, b) to break with the help of terror some of the clergy, to force it to cooperate with the NKVD and thus to undermine the authority of the church among our people in general" ${ }^{\prime 412}$.

\footnotetext{
${ }^{410}$ Швець І. Збірник. Статті, доповіді, промови. Сідней, 1996. С. 189.

411 Релігія в житті українського народу: зб. матеріалів. Мюнхен; Рим; Париж, 1966. C. 288.

412 Ibid. C. 289.
} 
Speaking of positive feedback on the decisions of the Lviv Council, only the representatives of the Orthodox Churches - Exarch of Bulgaria Stefan, Archbishop of New York, Carpathian-Rus' and of Vilna Corneliy, sent their congratulations to the Moscow Patriarch Alexy.

As for the scientific assessments of the Lviv Council itself and the decisions taken on it, in the church circles that have maintained the faithfulness to the union, and in scientific researches, the Council and the adopted resolutions are considered as illegitimate and noncanonical. Most contemporary church and secular scholars of the UGCC history follow these approaches. The essence of their position is as follows. The council in its current form was not legally able to resolve the issue of reunification of the churches. The meeting, referred to as the Council of the Ukrainian Greek Catholic Church, took place without the participation of any of its bishops, who were in prisons and exile. These facts automatically make it uncanonical, and the decisions made in that case were illegal because they grossly violated church laws established by the Ecumenical Councils. Therefore, according to church canons, none of the decisions of the Lviv Council can be considered legitimate.

Secondly, G. Kostelnyk was appointed head of the UGCC with the rights of its metropolitan not by the Vatican, that is, by the ecclesiastical authority, but by the decision of the Soviet regime, which, according to the provisions of the constitution for the separation of the church from the state, had no legal rights. In addition, the delegates of the council were not elected under canon law, and therefore could not legally and canonically represent the whole community of the clergy and the faithful. According to the historian of the church, Y. Fedoriv, "any council that goes against the will of hierarchs, without the participation of bishops, is not a council. Its decisions have no canonical significance. This (in theory) is also recognized by the Russian Orthodox Church",413.

According to Y. Herych, in accordance with church laws, the Russian Orthodox Church as a local church did not have the right to interfere in the internal affairs of another local church, especially the

${ }^{413}$ Федорів Ю. Історія Церкви в Україні. Торонто, 1967. С. 315. 
Greek Catholic, subordinated to the Vatican. Thus, in his opinion, the Soviet authorities, which, according to a secretly concluded plan and with the help of the repressive bodies and the ROC, liquidated the Greek Catholic Church in the territory of Ukraine, and formally consolidated this action with the Lviv pseudo-council in 1946, violated elementary human rights recognized worldwide, even in other totalitarian states ${ }^{414}$.

This view is supported by I. Bilas, who, comparing the liquidation of the Metropolitanate of Kyiv in 1839 and Lviv in 1946, concluded that the leader of the liquidation of the UGCC, G. Kostelnyk, was not its metropolitan, like Metropolitan J. Semashko was, he had no authority to convene the council in 1946, and did not seek the approval from the highest ecclesiastical authority. Thus, the council of 1946 was convened against all the rules of the Catholic Church. The council in Lviv aims to liquidate the Greek Catholic Church and therefore cannot be called a Greek Catholic. Therefore, all Catholics were morally obliged to reject the decisions of this council, because according to the norms of the Catholic Church, such a council is illegal. G. Kostelnyk also did not receive authority from the ROC, because he was not Orthodox. The council of 1946 could not be Orthodox for the reasons that the decisions of the council did not concern the Orthodox, but the non-Orthodox. Thus, Kostelnyk could only be authorized to convene such a council from the government of the UkrSSR. Since the council of 1946 solved matters of great importance that could drag the country into international complications, it is clear that G. Kostelnyk could not convene the council at his own risk and on his own behalf. Therefore, the council is not a private issue, but a state event.

The Lviv council of 1946 was the culminating moment of the antiunion policy of the Soviet authorities and aimed at the elimination of Greek Catholicism in Western Ukraine. In the course of the research, it was found out that the decision to convene the council was not made by church figures, even by members of the Initiative Group, but by the state security service. In the opinion of the special services, the council, as an action of church-canonical registration of the process of

414 Герич Ю. Як відбувався «возсоєдинительний собор» у Львові 8 березня 1946 р. Календар «Світла». Торонто; Нью-Йорк, 1995. С. 88-91. 
transfer of Greek Catholics to the jurisdiction of the ROC, had to formally complete the process of liquidation of the union in Galicia.

The political regime, which established itself in 1944 in the Western Ukrainian region, was of a totalitarian nature and acted exclusively by command, administrative, and repressive methods. The Communist Party, the majority of which were newly arrived Russians from the east, promoted the unification of the sociopolitical, economic, and church-religious life of the region in accordance with models in the Soviet Union. In this connection, mass deportations of patriotic Ukrainians to Siberia, as well as actions to discredit the Greek Catholic clergy and the new bishop of the UGCC, Josyf Slipyj, began. In response, the OUN leadership appealed to the population in July 1945 not to undergo conversion to Russian Orthodoxy $^{415}$.

However, after the devastating blows of totalitarianism, the Greek Catholic Church did not perish in the Precarpathian lands. It was reorganized in the catacombs and served underground for almost half a century.

In general, the catacomb period of church activity can be divided into three stages: 1) resistance to the repressive actions of the authorities, 1946-1953; 2) organizational revival of structures and activation of underground activities, 1953-1963; 3) the struggle for the preservation of the church and its legalization, 1963-1989. The most important, in our opinion, were the last years of the Stalin regime. Even before the Lviv "council", in April 1945, the entire ecclesiastical hierarchy - Metropolitan Josyf Slipyj and ten bishops were arrested and, on the verdict of the Military Tribunals in Kyiv, imprisoned for a long time ${ }^{416}$. None of them renounced their faith and loyalty to the Apostolic See in exchange for the freedom promised by the NKVD. Bishops Hryhory Khomyshyn, Josafat Kotsylovsky, Mykyta Budka, Hryhory Lakota died in prisons and in exile. The bishop of Mukachevo Theodore Romzha was killed in the fall of

415 Сергійчук В. Нескорена церква: Подвижництво греко-католиків України у боротьбі за віру і державу. Київ, 2001. С. 72-75.

${ }^{416}$ Від прокурора УРСР. Вільна Україна. 1946. 1 березня. 
$1947^{417}$. During 1945 - 1946, the Soviet security authorities arrested over 800 Greek Catholic priests and threw them into prisons and concentration camps ${ }^{418}$.

The main reason for the arrest was the resistance to conversion to Orthodoxy. "Arguments" of the power were accusations of "cooperation" with the Nazis (J. Slipyj blessed the soldiers of the "Galicia" division to fight the Red Army), as well as with the Ukrainian rebels, among which the chaplains served ${ }^{419}$.

As a result of resistance of the Greek Catholic clergy and believers, the implementation of the decisions of the Lviv "Council" has been extended for several years. At the end of 1947, only 1,124 of the 2,700 priests accepted Orthodoxy ${ }^{420} .312$ parishes were converted to orthodoxy ${ }^{421}$. According to information from the Lviv region, at the end of 1946, 101 parsons refused to convert to Orthodox Christianity, and in addition, 55 people were arrested. Many priests went on to secular life. In the region, the number of existing churches sharply decreased - to 269 , ie twice only in 1946 . The same pattern was observed in the Transcarpathian region, where in 1947 Malyi Berezny and Boroniav monasteries were liquidated, and 173 parishioners from 299 refused to leave their native church, even after 128 of them were arrested and sent to Siberia or Kazakhstan ${ }^{422}$.

With the active involvement of law enforcement, most Greek Catholic parishes have been converted to Orthodox. In particular, in 1946 Orthodox became 1685 temples, in 1947 - 222, 1948 - 56,

417 Пушкаш Л. Кир Теодор Ромжа. Життя і смерть єпископа. Львів, 2001. С. 77-135; Судоплатов П. Разведка и Кремль. Москва, 1996. С. 299-300; Баран В. Україна: новітня історія(1945-1991 рр.). Львів, 2003. С. 72.

${ }^{418}$ Gudziak B., Hurkina S., Turij O. Hierarchia i duchowieństwo ukraińskiego kościola grecko-katolickiego w podziemiu.Polska - Ukraina. 1000 lat sąsiedztwa. T. 4. Przemyśl, 1998. S. 311-312, 315.

419 ДАІФО.Ф. Р-389. Оп. 1. Спр. 4. Арк. 79.

${ }^{420}$ Ibid. Ф. 4648. Оп. 4. Спр. 4. Арк. 40.

${ }^{421}$ Gudziak B., Hurkina S., Turij O. Hierarchia i duchowieństwo ukraińskiego kościola grecko-katolickiego w podziemiu.Polska - Ukraina. 1000 lat sąsiedztwa. T. 4. Przemyśl, 1998. S. 315.

422 ЦДАВО України. Ф. 4648. Оп. 3. Спр. 8. Арк. 34; Бендас Д. Священики мученики, сповідники вірності. Ужгород, 1999. С. 72-74. 
1949 - 327; in 230 "unincorporated" temples the church service was terminated $^{423}$.

On the eve of the first arrests, the leaders of the Metropolitanate took care of the preservation of the church hierarchy. In the spring of 1945, Metropolitan Josyf Slipyj appointed four administrators of the Metropolitanate at once - his successors: Bishops Mykyta Budka (1877-1949) and Mykola Charnetsky (1884-1959), Archimandrite Klymentiy Sheptytsky, and J.de Vokht from the Order of Redemption $^{424}$. After the NKVD authorities arrested both bishops together with Metropolitan in April 1945, the Metropolitanate was headed by Fr. Klymentiy Sheptytsky. Because of his arrest in June 1947, the management moved to Fr. J. de Vokht, a Belgian citizen who had to leave Galicia at the end of 1948. I.Ziatyk became the head of the Metropolinate but the KGB authorities arrested him and sent to Siberia, where in 1950 a priest died of beating. The duties of the underground church leader were assumed by Fr. M. Khmiliovsky, who, under the pseudonym Mykhaylo Lavrivskyi was hidden in the survived female monasteries, appealed to the clergy and the faithful with letters, lifted their spirits in the struggle to preserve the church in the catacombs. At the same time, he cooperated with the Ukrainian underground of the OUN and the UPA. However, M. Khmiliovsky in 1949 was captured and sentenced to exile ${ }^{425}$. Remaining without a higher hierarchy, the local structures of the church continued to operate.

Similar measures to appoint his successors were taken before his arrest in April 1945 by Stanislav Bishop Hryhory Khomyshyn ${ }^{426}$. He ordained as bishops-assistants the professors of the Theological Seminary S. Lukach, S. Vapovych and I. Slesyuk and appointed Fr. G. Balagurko as the General Vicar of the eparchy, who had to succeed

\footnotetext{
423 Баран В. Україна: новітня історія (1945-1991 рр.). Львів, 2003. С. 72.

424 Кардинал Йосип Сліпий і сучасність. Івано-Франківськ, 2002. С. 125-128; Боцюрків Б. Українська Греко-католицька церква в катакомбах (1946-1989). Календар «Благовіста». 1998. С. 93.

${ }^{425}$ Gudziak B., Hurkina S., Turij O. Hierarchia i duchowieństwo ukraińskiego kościola grecko-katolickiego w podziemiu.Polska - Ukraina. 1000 lat sasiedztwa. T. 4. Przemyśl, 1998. S. 312.

426 Rublowa N. Świadectwo wiary... Polska-Ukraina. 1000 lat sąsiedztwa. T. 5. Przemysl, 2000. S. 123-127.
} 
him. However, in 1945 G. Balagurko, S. Lukach and I. Slesyuk were arrested, charged with "cooperation with the Germans", "organization of an illegal bishopric", "illegal ties with the Vatican" and sentenced to long terms of imprisonment. Only Fr. S. Vapovych managed to avoid arrest and escape to the Carpathians, but he could no longer manage the eparchy. The same was the situation in Transcarpathia. On the eve of the tragic death, Bishop Theodore Romzha consecrated Bishop Olexandr Hira. But as early as 1949, the heir was arrested and exiled to Siberia (died in 1983) ${ }^{427}$.

On September 20, 1948 one of the "initiators" of the "cathedral" in 1946, Fr. G. Kostelnyk was killed at the exit of the Church of Transfiguration in Lviv. The circumstances of his death and the organizers of the action have not been revealed till nowadays. Lviv archives, including the Security Service of Ukraine, do not even have investigation documents. Authorities have accused the OUN in the organization of a terrorist act (the murderer V. Pankov allegedly committed suicide) and used this to launch a new wave of repression against the liberation movement and the unconquered church. The secretary of the "group" Serhiy Khrutsky was evicted to the Kemerovo region. Another "initiator" was soon poisoned in a train when he returned from Moscow. The other members of the group died not by their own natural deaths ${ }^{428}$. The offensive against the priesthood has increased even more since the assassination of Yaroslav Halan in 1949 in connection with involvement in the action by priests. During this dramatic period, the Metropolitan, 10 bishops, 1400 priests and 800 UGCC monks and nuns were repressed. Even Greek Catholic icons were painted over ${ }^{429}$.

Despite the physical threats posed by law enforcement agencies, only half (116 of 235) of the Trans-Carpathian Greek Catholic priests accepted the jurisdiction of the Moscow Patriarchate by 1949. Therefore, in March 1949, the authorities initiated an appeal "To the Greater Clergy and All Pious Believers of the Greek Catholic Church

\footnotetext{
427 Пекар А. Нариси історії Церкви Закарпаття. Т. 2. Рим; Київ, 1997. С. 491.

${ }^{428}$ Пащенко В. Греко-католики в Україні (від 40-х років ХХ століття до наших днів). Полтава, 2002. С. 106; ЦДАГО України. Ф. 1. Оп. 24. Спр. 3613. Арк. 1-2. ${ }^{429}$ Винниченко І. Україна 1920-1980-х рр.: депортації, заслання, вислання. Київ, 1994. С. 62; ДАТО. Ф. Р.3270. Оп. 2. Спр. 17. Арк. 30.
} 
in Transcarpathia", signed by the rectors of six churches and monasteries led by Archdeacon Irynei Kondratovych (1881-1957), a former member of the Communit Party of Hungary (1919). These priests performed similar functions as G. Kostelnyk's group in Lviv. On August 28, 1949, a group of 35 priests proclaimed the liquidation of the Uzhgorod Union in 1646 and reunited with the ROC. On the same day, thousands of believers who traditionally gathered for the Feast of the Assumption of the Virgin Mary at the Holy Nicholas Monastery on Chernecha Mountain in Mukachevo, learned of this "joyful" action ${ }^{430}$. And only about 80 parishes with 44 churches of the Mukachevo Eparchy, which appeared in Slovakia in 1944, were registered at the Apostolic Administration of the Mukachevo Eparchy (General Vicar A. Tynk), which Rome canonically subordinated to the jurisdiction of the Bishop of Presov ${ }^{431}$.

Despite the persecution, much of the Greek Catholic clergy continued to resist the communist regime. It took various forms and methods: active - outright refusals to accept Orthodoxy, agitation among the faithful, or passive - formal rejection of their parishes and the underground service of the church rituals ${ }^{432}$.

The OUN and UPA leadership led a decisive fight against the forcible conversion of the population of the region to Orthodoxy, openly threatened to converted parishes and sometimes committed terrorist acts against them. In particular, four priests were killed in the Stanislaviv region before $1952^{433}$. A large number of priests, including those who were forced to convert to Orthodoxy, worked closely with the Ukrainian underground. The monks of the Hoshiv Monastery cared for the wounded rebels and raised money for them $^{434}$. At the end of 1952 in the Stanislav region under the influence of the OUN fighters, 63 parishioners refused to leave the

\footnotetext{
430 ЦДАВО України. Ф. 4648. Оп. 3. Спр. 80. Арк. 31; Пащенко В. Грекокатолики в Україні (від 40-х років XX століття до наших днів). Полтава, 2002. С. 126-129; Сергійчук В. Нескорена церква: Подвижництво греко-католиків України в боротьбі за віру і державу. Київ, 2001. С. 155.

431 Пекар А. Нариси історії Церкви Закарпаття. Т. 2. Рим; Київ, 1997. С. 324.

432 ДАІФО. Ф. Р-389. Оп. 1. Спр. 6. Арк. 123; ДАТО. Ф. П-1. Оп. 1. Спр. 2345. Арк. 76.

Андрухів І. Галицька Голгофа. Івано-Франківськ, 1997. С. 38.

${ }^{434}$ ЦДАГО України. Ф. 1. Оп. 24. Спр. 13. Арк. 1-14.
} 
UGCC. There were 70 church communities operating here. At the same time, 22 priests returned to the Stanislaviv Orthodox Bishop a certificate of adherence to Orthodoxy ${ }^{435}$.

Large-scale force and propaganda campaigns succeeded in converting 1124 priests to Orthodoxy and handing over 2,500 churches in Western Ukraine to the ROC. At the initiative of the USSR government, Greek Catholic parishes were liquidated in Romania in 1948, and in April 1950 the hierarchs of the Eparchy of the Greek Catholic Church in Czechoslovakia were arrested and converted to Orthodoxy. Bishop Pavel Gojdic, sentenced to life in prison, died there; Assistant Bishop V. Hopko was only released during the "Prague Spring" in 1968, when the Greek Catholic Church became legalized ${ }^{436}$. In 1944-1956, the activities of the Greek Catholic communities were also suspended in Poland (the General Vicariate was created in 1967, the Przemysl Eparchy was established in 1991, and the Przemysl-Warsaw Metropolinate of UGCC was established in 1996) ${ }^{437}$.

The monks gave the great resistance to totalitarian authorities, only a few of them denied the union. Despite the brutal repression and harassment, by the end of the 1940's there were three in the Lviv region, and six Greek Catholic monasteries in the Stanislav region (Pidmykhailivtsi, Hoshiv, Voynyliv, Stanislav) ${ }^{438}$. Believers from the surrounding villages, where the Greek Catholic communities had already been liquidated, came to the monasteries and convents in Hoshiv in the Bolekhiv district. Consequently, the priests and monks continued their religious activities as parish priests and catechists.

\footnotetext{
435 Андрухів І. Галицька Голгофа. Івано-Франківськ, 1997. С. 38.

${ }^{436}$ Ісіченко І., архиєп. Історія Христової церкви в Україні. Харків, 1999. С. 200; Пекар А. Нариси історії, церква Закарпаття. Т. 2. С. 282-380; Магочі П. Пряшівська греко-католицька єпархія: русинська чи словацька церква? Ковчег. Ч. IV. Львів, 2003. С. 170-173.

${ }^{437}$ Ukraińcy w najnowszych dziejach Polski(1918-1989). T. 1 / Pod red. R. Drozda. Slupsk; Warszawa, 2000. S. 159-184; Drozd R. Polityka władz wobec ludności ukraińskiej w Polsce w latach 1944-1989. Warszawa, 2001 S. 30-307; Козак М. Пом'яни, Господи, душі слуг твоїх. Перемишль; Львів, 2002. С. 14-22.

438 ЦДАВО України. Ф. 4648. Оп. 3. Спр. 80. Арк. 34; ЦДАГО України. Ф. 1. Оп. 24. Спр. 12. Арк. 96-105.
} 
On September 29, 1949, in a report to Nikita Khrushchev, P. Vilkhovy, the Commissioner of the Council for Religious Cults under the USSR Council of Ministers on the UkrSSR, stated his deep concern of such a situation. And in the beginning of December of the same year he was received by the Deputy Chairman of the Council of Ministers of the UkrSSR Leonid Korniets, with whom he discussed "proposals for the liquidation of all monasteries". Therefore, the "commissioner" prepared proposals for the closure of three Greek Catholic monasteries in Lviv region, and on December 9, 1949 L. Korniets sent to the head of the Lviv regional executive committee Semen Stefanyk "instructions for taking measures". However, he didn't had strong intentions to go against public opinion ${ }^{439}$. The female monasteries survived for the longest period, especially in the village Sukhovoly (till 1952) and the city of Lviv (till 1957). The activity of all the others were ceased by the Soviet authorities in 1950 , when, as a result of mass repression, about one hundred nuns and forty female servants were arrested and deported to Siberia and the Far East, 29 of whom died in exile ${ }^{440}$. Those who left have created smallcongregations, mostly in private urban dwellings. They continued to work as nurses, seamstresses, cleaners, and at the same time served as liaison between clergy and laymen ${ }^{441}$.

By the early 1950s, the Soviet government officially abolished five Greek Catholic eparchies and two apostolic administrations, and imprisoned all the rulers. From the Greek Catholic bishops, Ivan Buchko, who in 1945 was named by the Pope as an exarch and apostolic visitor for Ukrainian Catholics in Western Europe, remained at freedom (he was in the Vatican). As evidenced by the certificate of the Commissioner for Religious Cults under the USSR Council of Ministers of the UkrSSR, P. Vilkhovy, from October 6, 1949 in the

\footnotetext{
439 Сергійчук В. Нескорена церква: Подвижництво греко-католиків України в боротьбі за віру і державу. Київ, 2001. С. 232; ЦДАГО України. Ф. 1, оп. 24, спр. 12, арк. 97-99.

${ }^{440}$ Боцюрків Б. Українська Греко-католицька церква в катакомбах (1946-1989). Календар «Благовіста». 1998. Гурово Іловецьке, 1998. С. 94; Сергійчук В. Нескорена церква: Подвижництво греко-католиків України в боротьбі за віру і державу. Київ, 2001. С. 253-260.

441 Сапеляк А. Київська церква на слов'янському сході. Буенос-Айрес; Львів, 1999. C. 188.
} 
western regions there were closed all existing Greek Catholic temples, including in Drohobych - 658, Stanislav - 567, Lviv - 522, Trenopil - 539, Chernivtsi - 2, Volyn - 2, as well as the bigger part of the monasteries ${ }^{42}$. However, only one-third of the priests converted to Orthodoxy, $15 \%$ were saved by escape or emigration, and half of those who were removed from the service, were repressed or converted to church underground ${ }^{443}$.

Under these conditions, parishioners for the most part kept loyalty to the faith of their fathers, so often they confessed only to their former pastors and boycotted the Orthodox priests. As a result, for example, eight priests were changed in Zhovkva, Lviv region in $1946-1949^{444}$. In the Stanislav region in 1949 , there were only 276 priests in 605 churches. The situation has not improved over the next four years: in 1953, there were only 240 priests in the 614 operating churches ${ }^{445}$.

The church service of the Greek Catholic rite by the Orthodox priests, at the request of parishioners, was a common phenomenon. This was a form of resistance to the Soviet regime and $\mathrm{ROC}^{446}$.

Metropolitan Josyf Slipyj, in the difficult conditions of exile, sent pastoral letters to the clergy and faithful, which were spread throughout the believers. For example, on the occasion of Christmas 1947, he called on all Greek Catholics to steadfastly withstand the persecution of the authorities, to remain faithful to their father's faith and to the church that had always served their people faithfully ${ }^{447}$. Together with Metropolitan, dozens of oppositional priests, who continued pastoral activity in prisons, concentration camps, and settlements, were exiled.

\footnotetext{
442 Сергійчук В. Нескорена церква: Подвижництво греко-католиків України в боротьбі за віру і державу. Київ, 2001. С. 220.

443 Ісіченко І., архиєп. Історія Христової церкви в Україні. Харків, 1999. С. 200-201; Архів УСБУ по Львівській обл. Спр. о. Матея (Шипітки). П-34395. Арк. 57, 69, 107, 269.

${ }^{444}$ ЦДАВО України. Ф. 4648. Оп. 3. Спр. 70. Арк. 28.

445 Андрухів І. Галицька Голгофа. Івано-Франківськ, 1997. С. 38-50.

446 Боцюрків Б. Українська Греко-католицька церква в катакомбах (1946-1989). Календар «Благовіста». 1998. Гурово Іловецьке, 1998. С. 95.

447 Мартирологія українських церков. Т. II: Українська Греко-католицька церква. Торонто; Балтимор, 1987. С. 470.
} 
The death of J. Stalin in March 1953 gave rise to wide hopes of legalization of the church. In the same year, there were recorded the first complaints of believers and the clergy about the return of the religious buildings, which were given to the collective farms and various organizations. Moscow, in the person of the "reformer" L. Beria, even began negotiations with Metropolitan Josyf Slipyj ${ }^{448}$, as evidenced by his letter to the then secretary of the Central Committee of the Communist Party of Ukraine, M. Pidhorny, sent to Kyiv in January $1961^{449}$. Being inprisoned, Metropolitan wrote a "History of the Ecumenical Church in Ukraine", which was confiscated by the Interior Ministry, and its author was sentenced in 1959 to eight more years of exile.

On March 27, 1953, there appeared a decree of the Presidium of the Supreme Soviet of the USSR on the amnesty of the prisoners, who had to stay in jail up to five years. In addition, in September a decree gave the Supreme Court the right to review the infamous decisions of the NKVD "triples" and the special meeting of the NKVD-KGB-MIA of the USSR, which affected most of the repressed Greek Catholics. Thus, during the Khrushchev "thaw", tens of thousands of exiles returned to their native land, including liberated Greek-Catholic priests ${ }^{450}$. By March 1957, 65.5 thousand Ukrainians had arrived, many of them were priests. On August 6, 1956 a letter to the chairman of the ROC Committee of the USSR Council of Ministers from Kyiv reported that of the repressed 344 Uniate priests there returned to the western Ukraine 243 of them. Most of them have already started religious activities, did a service, campaigned against the ROC and its patriarch Alexy. Numerous statements were received by the authorities from the believers with the requirements of the UGCC rehabilitation, registration of church communities in accordance with the Constitution ${ }^{451}$.

\footnotetext{
448 Пащенко В. Греко-католики в Україні (від 40-х років ХХ століття до наших днів). Полтава, 2002. С. 151.

449 Сліпий Й., митр. Історія Вселенської церкви на Україні. Т. 4, ч. 1. Рим, 1996. С. 1-3; Архів Служби безпеки України. Спр. 87. Т. 10. Арк. 278; Т. 5. Арк. 295.

450 Сергійчук В. Нескорена церква: Подвижництво греко-католиків України в боротьбі за віру і державу. Київ, 2001. С. 285-288; Пащенко В. Греко-католики в Україні (від 40-х років ХХ століття до наших днів). Полтава, 2002. С. 146-147; Арсенич П. Йосиф Сліпий та його соратники - репресовані священики. Кардинал Йосиф Сліпий і сучасність. С. 126-127.

${ }^{451}$ ЦДАГО України. Ф. 1. Оп. 24. Спр. 4263. Арк. 202-205.
} 
We should agree with the researchers that 1953 can be considered the last year of the internal crisis, in which the repressed church was after the so-called Lviv "council"" 52 .

The repressed Uniate priests were financially and morally supported by the Roman Catholic clergy of Transcarpathia, Drohobych and Lviv regions. For the Oriental Catholics, church services were often celebrated during the Orthodox holidays in accordance with the Greek Catholic rite ${ }^{453}$.

Of great importance for the catacomb church was the return of hierarchs, in particular Bishop M. Charnetsky to Lviv in 1956, Bishop I. Lyatyshevsky to Stanislav, and Bishop O. Hira to Mukachevo. Despite constant surveillance and the threat of repression, they primarily restored church structures, strengthened the church organizationally, and cared for the replenishment of clergy to work underground. In April 1959, Bishop M. Charnetsky ordained fifty priests during the two years before his death. He accepted another 280-300 priests to the UGCC from the Orthodox Church. They wished to return to their native church, officially remaining in the service $^{454}$. Bishop I. Lyatyshevsky (1870-1957), although the relevant Soviet authorities monitored and recorded all his visitors, united priests in Stanislaviv region, formed an initiative group for the revival of the UGCC, which made numerous statements to the authorities. The number of unbundled parsons in the area has increased to $84^{455}$. They conducted extensive pastoral work, although the authorities persecuted them, searched, seized church books, and imposed penalties. Often, non-Orthodoxy communities opened their own churches in which underground clergy send the Divine Service (usually on major religious holidays). In 1958, 14 Greek Catholic churches operated in the Stanislaviv region ${ }^{456}$. Widespread listening

\footnotetext{
452 Пащенко В. Греко-католики в Україні (від 40-х років ХХ століття до наших днів). Полтава, 2002. С. 143.

453 Сергійчук В. Нескорена церква: Подвижництво греко-католиків України в боротьбі за віру і державу. Київ, 2001. С. 236; Пащенко В. Греко-католики в Україні (від 40-х років ХХ століття до наших днів). Полтава, 2002. С. 168-169.

454 Бойко I. Владика Миколай Чарнецький: ісповідник, мученик, чудотворець. Львів, 1997. С. 61.

455 ДАІФО. Ф. Р-389. Оп. 2. Спр. 18. Арк. 102-103.

456 Андрухів І. Галицька Голгофа. Івано-Франківськ, 1997. С. 55-56.
} 
to religious radio broadcasts from the Vatican, which was organized specifically for Greek Catholics in Ukraine, has become common.

It is clear that the process of returning from exile of the opposition clergy was extremely disturbing to the authorities of the western regions of Ukraine. On April 6, 1955, in a letter to Moscow, the secretary of the Lviv Regional Party M. Lazurenko reported that there returned to Ukraine 30 former priests of the UGCC and the former General Vicar of the Metropolitan, M. Khmilevsky, who was secretly ordained as a bishop, and who had been sentenced for 10 years in prison in 1950 for cooperation with the OUN and UPA and a relationship with the Vatican. M. Lazurenko complained that almost all of them conduct "activities hostile to the Soviet authorities", keep contacts with Metropolitan J. Slipyj and other UGCC hierarchs in exile, provide them with material assistance ${ }^{457}$.

After returning from their places of imprisonment, Greek Catholic priests became actively involved in the activities of the catacomb church. In a report to Moscow on December 10, 1956, the commissioner of the ROC Affairs Council under the Council of Ministers of the UkrSSR, Korchovy, reported that of the 267 priests, who returned, only 14 agreed to lead Orthodox parishes, while the rest held underground worship in the Greek Catholic rite, became the "moral base of the OUN underground" "58. Therefore, the Soviet authorities took all measures to combat the UGCC, involving the Russian Orthodox Church. A special meeting of the ROC Affairs Council under the Council of Ministers of USSR, on April 10, 1959, adopted a secret resolution to strengthen the work to "eliminate the remnants of the union in the western regions of the USSR", which envisaged the activation of the Moscow Patriarchate of the Orthodox priesthood against the underground UGCC. The priests were asked to expose the Vatican as the enemy of Orthodoxy and the instigator of the Cold War, to combat the clandestine activities of the Uniates, to bring their cases to court, to evict outside the regions, to register only Orthodox Church communities, to suspend the payment of pensions to the families of the inprisoned priests ${ }^{459}$. However, this counterpropaganda was ineffective.

\footnotetext{
${ }^{457}$ ЦДАГО України. Ф. 1. Оп. 24. Спр.4081. Арк. 2-5.

458 ЦДАГО України. Ф. 1. Оп. 24. Спр. 4263. Арк. 288-300.

459 Ibid. Оп. 24. Спр. 5028. Арк. 65-67.
} 
The international community also opposed the lawlessness in the USSR. In December 1962, at a meeting with M. Khrushchev, US Ambassador N. Kazens sent a request to J. Kennedy and Pope John XXIII to release Metropolitan J. Slipyj. Therefore, at the beginning of February 1963, Metropolitan left for Rome, where he participated in the Second Vatican Council as the head of the UGCC. On his way, during his short stay in Moscow, he consecrated as a Redemptorist Bishop the Abbot Vasyl Velychkivsky and appointed him as a head of the UGCC in the underground ${ }^{460}$.

Metropolitan J. Slipyj was active in Rome. Already in 1963, the Ukrainian Catholic University of St. Clement the Pope was established. On the following year, the monastery for the monksstudents was opened, as well as the cathedral of Saint Sophia - the spiritual center of the Ukrainian Greek Catholics, and the publication of the magazine "Theology" was established. Metropolitan kept in touch with the region (mainly through Poland), sent pastoral letters, and provided information on the activities of the religious underground. Pope Paul VI named J. Slipyj the Supreme Archbishop of the Ukrainian Catholic Church and Cardinal. Appointment of V. Velychkovsky as Archbishop by J. Slipyj proved to be an extremely successful choice. It led to the extensive construction of the UGCC in the catacombs. At his initiative, the process of returning Orthodox priests was initiated. V. Velychkovsky founded three secret women's monasteries in Lviv: Monastery of the Servants, of St. Basil and St. Victoria, where girls made monastic vows. At a secret residence in Lviv, he met with the General Vicar of Przemysl, V. Hrynyk, through whom he maintained regular contact with Cardinal J. Slipyj. In case of a new arrest (and he had already served 10 years of exile), V. Velychkovsky in 1964 consecrated Volodymyr Sternyuk as a Bishop and Chorniy, N. Deyneka, P. Kozak and J. Girnyak as Assistant Bishops. In 1967 he reported to Cardinal J. Slipyj that 150 parishioners, over 100 Basilians, 60 students, 54 redemptorists were active in Galicia and

460 Чернега М. Життя і терпіння Спископа Величківського. Нова зоря. 1997. 27 травня; Сергійчук В. Нескорена церква: Подвижництво греко-католиків України в боротьбі за віру і державу. Київ, 2001. С. 402, 403, 404, 412, 416, 422. 
Transcarpathia. There were 240 Basil nuns in 14 secret houses. About 50 priests converted from Orthodoxy, 40 more were ordained ${ }^{461}$.

One of the biggest problems of the catacomb church in the 1960s was the replenishment of the Greek Catholic priesthood. By this time the reserve of the former seminarians, the monks who had escaped arrest, had run out. It was from this environment that Bishop M. Charnetsky consecrated fifty priests after a short period of study. There was a need to train priests from the young generation, who grew up in the conditions of a totalitarian system, which was dominated by the atheistic ideology. The undergraduate seminary courses mostly involved the sons and relatives of the Greek Catholic priests and lay activists. In addition, the training of candidates in the Orthodox seminary, as well as the Roman Catholic ones in Riga and Kaunas, was practiced. Underground training lasted 4-6 years or more in private homes with several and sometimes with one candidate ${ }^{462}$. Having successfully passed the exams before the priests, the students were allowed to be consecrated by the bishops V. Velychkovsky, V. Sternyuk and others. The consecration of Lviv candidates by the bishops of Stanislav and vice versa was practiced for conspecific purposes.

It should be noted that in the conditions of the underground activity the church structure, in particular the system of subordination, had its own peculiarities. The so-called "old" priests, ordained before 1946, recognized the rule of bishops of their diocese, that is, still under legal conditions. Priests, consecrated in the underground, obeyed the bishops who consecrated them. The priests acted independently, with almost no one working in their native places. From time to time, secret meetings have been organized, in particular in the city of Lviv - at home of Olena Kulchytska or in Transcarpathia. Those priests who formally adopted Orthodoxy also participated. The activities of the UGCC brought the hierarchy closer to the priesthood; the bishops worked directly among the people, and this fact positively influenced the Ukrainian society, facilitated its consolidation.

\footnotetext{
461 Gudziak B., Hurkina S., Turij O. Hierarchia i duchowieństwo ukraińskiego kościola grecko-katolickiego w podziemiu.Polska - Ukraina. 1000 lat sasiedztwa. T. 4. Przemyśl, 1998. S. 323.

462 Стоцький Я. Монастир Отців Василіян Чесного Хрес та Господнього в Бучачі 1712-1996. Львів, 1997. С. 135.
} 
Although the confrontation between the Greek Catholic Church and the Soviet authorities never ceased, the Khrushchev "thaw" days and the first years after its displacement in 1964 brought some relief from anti-religious pressure. This made it possible to restore the structure of the previous metropolis. Bishop V. Velychkovsky headed the Archdiocese of Lviv until his arrest in 1969. He had assistant priests A. Zofiyovsky and I. Chornyak, and in 1964 consecrated as the successor the Redemptorist Fr. Volodymyr Sterniuk. The IvanoFrankivsk Eparchy was ruled by Bishop Ivan Slesyuk (1893-1973), who consecrated as an assistant and successor Fr. S. Dmyterko. The Mukachevo-Uzhhorod Eparchy was governed by Bishop O. Hira. According to Fr. B. Botsyurkiv, in 1968 several hundred GreekCatholic priests, about 480 nuns, who were united in 14 secret religious houses, were active in Ukraine. The core of the church was the monastic orders - about 240 Basilians, students, and Redemptorists. 40 priests were ordained, 50 returned from Orthodoxy, 20 candidates were trained. In some localities, Greek Catholics opened closed temples and invited clergymen to attend. In fact, 88 Greek Catholic churches operated in western Ukraine ${ }^{463}$.

In these circumstances, governmental institutions have made a number of important decisions to combat both the "illegal activities of the Uniate Church and sectarians" and religion in general. In 1969, Bishop V. Velychkovsky, as well as prominent priests P. Horodotsky in Lviv and R. Bakhtalovsky in Kolomyia were arrested, searches were made in the premises of Bishop V. Sterniuk, in the premises of dozens of priests and monks. Many churches were removed from registration. The offensive on religion and the UGCC continued over the coming years, however, in less brutal forms. The KGB has widely used provocations to discredit the Greek Catholic hierarchy, including Bishop Volodymyr Sterniuk. In 70 closed temples of the western region, the authorities have equipped anti-religious, especially antiUniate museums and galleries, which, along with other factors, carried out ideological treatment of the population ${ }^{464}$.

M. Pidhorny's meeting with Pope Paul VI in 1967 and the events in neighboring Czechoslovakia in 1968 and the revival of the Greek

\footnotetext{
463 Боцюрків Б. Українська Греко-католицька церква в катакомбах (1946-1989). Календар «Благовіста». 1998. Гурово Іловецьке, 1998. С. 102.

464 Пащенко В. Православ'я в новітній історії України. Ч. 2. Полтава, 2001. C. 306 .
} 
Catholic Church there have intensified the activities of the clergy and faithful of the UGCC in western Ukraine. The message issued by the commissioner of the Council of Religious Affairs also did not help. It stated unequivocally that the Greek Catholic communities would not be registered as the UGCC was liquidated and the priests and initiators of the unlawful opening of Uniate churches would be punished by 10 years in prison. Applications for legalization of the UGCC continued to be received. The authorities were gravely concerned about the Ukrainian dissidents advocating for the UGCC. In the early 1970's Moscow launched a broad campaign to combat "Ukrainian nationalism". Seeing in the awakening of national consciousness a direct threat to the totalitarian communist regime, the Soviet authorities resorted to arrests and other repressive actions in order to intimidate the people and stop the national movement. The peak of the repressions occurred in 1972-1973. In December 1973, there were arrested bishops S. Dmyterko and I. Slesyuk, several priests. Soon, underground priests I. Kryvyi and P. Chuchman were murdered.

Helsinki agreements forced the Kremlin to weaken the offensive; on the other hand, they started legal movement for human rights. The coming to the Apostolic See of Pope John Paul II in 1978 intensified the Vatican's policies for the protection of the UGCC. In a letter to the Soviet government, the Holy Father, referring to the Universal Declaration of Human Rights, signed by L. Brezhnev in 1975, urged not to make obstacles to the believers. Moscow was particularly disappointed with the resolution of the Synod of Ukrainian Bishops in Rome of December 2, 1980, on the non-canonical charscter of decisions of the Lviv Council in $1946^{465}$.

Despite persecution and arrests, on September 9, 1982, an "Initiative Group for the Protection of the Rights of Believers and the Church" was formed. It was run by the later arrested and imprisoned dissidents J. Terelia and V. Kobryn, who set up the publishing house "Chronicles of the Catholic Church in Ukraine". The movement for the legalization of the church, to which the Ukrainian Helsinki Group and other opposition structures joined, had intensified ${ }^{466}$.

\footnotetext{
465 Боцюрків Б. Українська Греко-католицька церква в катакомбах (1946-1989). Календар «Благовіста». 1998. Гурово Іловецьке, 1998. С. 114.

466 Пащенко В. Православ'я в новітній історії України. Ч. 2. Полтава, 2001. С. 318; Історія України. Вид. 2-е. Львів, 1998. С. 381-401.
} 
During the 1980s, the UGCC lost its prominent hierarchs. On September 7, 1984, the Archbishop of Lviv, Cardinal Josyf Slipyj died in Rome. His successor was Myroslav Ivan Lyubachivsky, Cardinal since 1985. Bishop Olexandr Hira died in exile in Kazakhstan.

With the democratization of the USSR, almost all political prisoners, including Greek Catholic priests, were released in the late 1980s. They led the national movement for human rights and freedoms. Established in 1987 in Lviv, the Committee of Defence of the Ukrainian Catholic Church, under the leadership of Ivan Gel, published the magazine "Christian Voice", organized large gatherings of believers, and signed petitions for the legalization of the UGCC. In the same year, a group of Ukrainian Catholic clergy led by Bishop Pavlo Vasylyk announced their departure from the underground. Bishop V. Sternyuk, S. Dmyterko, and I. Marhitych were openly demanding the revival of the UGCC. This movement was especially intensified in connection with the state-level celebration of the 1000th anniversary of the baptism of Rus'-Ukraine. The UGCC actually went out of the underground, becoming a significant factor in Ukrainian statemaking ${ }^{467}$.

Thus, in the 1950s and 1980s, most Greek Catholics maintained the faith of their parents. Hundreds of priests continued their pastoral illegal activities, which intensified in the late 1950s - early 1960s after the return of a large proportion of prisoners from the Siberian camps and settlements. The repressed church was an expression of universal values, unlike the official one, which was an element of the ideological policy of the totalitarian system. Gorbachev's proclamation of a course on the restructuring and democratization of society created the conditions for church and religious revival in the UkrSSR, which was fully used by the political opposition and millions of believers. The religious opposition prepared the ground for the final stage of the struggle for the democratization of society, the return of its people to the world civilization.

467 Дідула П. Щоб не зрадити ідеї патріархату. Патріархат. 2002. № 3. С. 12-13. 